\title{
The citotoxicity of calcium hydroxide intracanal dressing by MTT assay
}

\author{
Nanik Zubaidah \\ Department of Conservative Dentistry \\ Faculty of Dentistry Airlangga University \\ Surabaya - Indonesia
}

\begin{abstract}
Calcium hydroxide had been used as the intracanal dressing in endodontic treatment due to its high alkaline and high antimicrobial capacity. It also be able to dissolve the necrotic tissue, prevent the root resorbtion and regenerate a new hard tissue. The aim of this study is to identify the concentration of calcium hydroxide that has the lowest citotoxicity. There are 5 groups, each group had 8 samples with different concentration of calcium hydroxide. Group I: 50\%, Group II: 55\%, Group III: 60\%, Group IV: 65\% and Group V: 70\%. The citotoxicity test by using enzymatic assay of MTT [3-(4.5-dimethylthiazol-2yl) ]-2.5 diphenyl tetrazolium bromide, against fibroblast cell (BHK-21). The result of susceptibility test was showed by the citotoxicity detection of the survive cell of fibroblast that was measured spectrophotometrically using $595 \mathrm{~nm}$ beam. The data was analyzed using One-Way ANOVA test with significant difference $\alpha=0.05$ and subsequently LSD test. The result showed that in concentration 50\%, 55\%, 60\%, 65\%, and 70\% calcium hydroxide had low toxicity, but calcium hydroxide 60\%, had the lowest toxicity.
\end{abstract}

Key words: calcium hydroxide, citotoxicity, MTT assay

Correspondence: Nanik Zubaidah, c/o: Bagian Konservasi Gigi, Fakultas Kedokteran Gigi Universitas Airlangga. Jln. Mayjend. Prof. Dr. Moestopo no. 47 Surabaya 60132, Indonesia.

\section{INTRODUCTION}

To day calcium hydroxide $\left[\mathrm{Ca}(\mathrm{OH})_{2}\right]$ is prefere drug used as intracanal dressing in dentistry especially in endodontic treatment. In 1920 the first time Herman used calcium hydroxide to nonvital dental treatment. In modern endodontic treatment, calcium hydroxide is introduced as intracanal dressing which is used in post intracanal preparation to obtain sterile intracanal. The principe of intracanal treatment including preparation sterilization and filling intracanal in which all of them are interrelated. ${ }^{1,2}$

The form of calcium hydroxide would be a powder or paste. Calcium hydroxide paste is a mixture of calcium hydroxide powder and steril distilled water or combination with other solvent such as: steril physiological saline solution, local anesthetic solution (citanest-octapressin 3\%), camphorated monochlorophenol (CHKM) etc. Calcium hydroxide $50 \%$ (50 gram calcium hydroxide powder/ $100 \mathrm{ml}$ sterile distilled water can be clinically used in routine practices (according to the direction of manufactor). ${ }^{3,4}$

Now day endodontic material with calcium hydroxide as raw material is available in the market and it is used for intracanal dressing paste in various trade mark and common by expensive will beneficially in routine application and cheap. Pure calcium hydroxide in endodontic treatment is expected to be clinically applied as intracanal dressing. ${ }^{5}$

Cohen and Burn ${ }^{6}$ reported that calcium hydroxide was chosen as intracanal dressing due to the properties such as: antimicrobial capacity and capable to regenerate a new hard tissue, to dissolve pulp necrotic, to penetrate accessories root canal and dentinal tubuli so that it could decrease permeability of dentinal surface, to dry excessive excudate because of the presence of calcium ion so that it could decrease permeability of capillary vessel and also Irritation and inflammation on the tooth apical will not occur during excessive filling of calcium hydroxide pasta. ${ }^{7}$ The above opinion is in contradiction with Vajrabhaya's ${ }^{8}$ opinion stated that the use of calcium hydroxide pasta in filling intracanal dressing, if it flows out of intracanal would cause tissue irritation, while, Stock and Nehamer ${ }^{9}$ suggested the use of excessive calcium hydroxide intracanal dressing resulting irritation on periapical tissue as well as on healthy, survive tissue and could slow down the healing process. Calcium hydroxide is dangerous if it flows out of periapical and enters alveolaris inferior canal resulting neurotoxic. ${ }^{10}$

The prolong use of calcium hydroxide intracanal dressing in root canal, therefore, biocompatibility factor is absolute requirement in addition non toxic, either locally or systemically will not irritate biological environment. ${ }^{11,12}$ Citotoxicity test on a tissue is one of the tests to determine toxic effect of a material or medicine. Citotoxicity test is one of methods evaluate to dentistry material for its direct toxicity to cell. Enzymatic assay is applied to measure citotoxicity of a material using MTT 3-[4.5-dimethylthiazol2-yl]2.5 diphenyl tetrazolium bromide. MTT enzymatic test is to measure the capability of survive cell based on 
mitochondria activity of cell culture. The test is mostly used to measure quantitatively cellular proliferation or to measure the number of survive cell. ${ }^{11,13}$

Based on the above description, the problems appear: how is the citotoxicity of calcium hydroxide as intracanal dressing using MTT method? The purpose of the present study is to determine the concentration of calcium hydroxide with low citotoxicity and the advantage is to provide for scientific information dentist and people that proper concentration of calcium hydroxide could be used as intracanal dressing resulting good endodontic treatment.

\section{MATERIAL AND METHOD}

The study is experimental laboratory and the study design is the post test only controlled group design, done in the laboratory of Tropical Disease Center (TDC), Airlangga University. Performing citotoxicity test calcium hydroxide is in Pusat Veterina Viafarma (PUSVERMA) for processing cell culture in which the cell was taken from Baby HamsterKidney-21(BHK-21) specifically from Kidney fibroblast of baby hamster and L-929 cell was taken from lung fibroblast of a mouse. ${ }^{14}$

Device and material were :pure calcium hydroxide powder (no. M2047, Merck, Darmstadt,Germany), sterile aquabidest (kimia farma), fibroblast cell culture (BHK21), stock pusvetma passage 52, trypsin versene solution, Media Rose Well Park Memorial Institute(RPMI)-1640 containing hepes $6 \mathrm{gr} / \mathrm{lt}$, pen strep $100 \mathrm{ml}$, bovine serum $10 \%$, Phosphatase Buffer Saline (PBS) solution containing $\mathrm{Na} \mathrm{Cl} 8$ gr, $\mathrm{KCl} 0.2$ gr, $\mathrm{Na}_{2} \mathrm{HPO}_{4} 1.15$ gr $\mathrm{KH}_{2} \mathrm{PO}_{4}$ in 0.2 gr steril distilled water 1 lt, MTT(Sigma Cat. No. M-5655) Dimethyl Sulfoxide (DMSO) (MP Biomedical, LLC, Catalog 190186 Lot .R.19953), 96 microplates, roux bottle spectrophotometer $595 \mathrm{~nm}$, micro pipette, eppendorf, cement spatel.

Sample groups of calcium hydroxide paste were classified into 5 groups for citotoxicity test consisting of group I (Calcium Hydroxide 50\%), group II (Calcium Hydroxide 55\%), group III (Calcium Hydroxide 60\%), Group IV (Calcium Hydroxide 65\%), and group V(Calcium Hydroxide $70 \%$ ). The process of making calcium hydroxide in concentration $50 \%, 55 \%, 60 \%, 65 \%, 70 \%$ was obtained by mixing powder of calcium hydroxide which had been measured according to the desired weight with sterile aquabidest until it become paste form the mixture was done in eppendorf tube and stirred using cement pastel for 1 minute, then, homogenization was done with vortex for 30 seconds. ${ }^{15}$

Calcium hydroxide solution was made ie: various concentration $50 \%, 55 \%, 60 \%, 65 \%$ and $70 \%$ by having calcium hydroxide and was sterilized using ultra violet for 30 minutes. Calcium hydroxide was mixed with sterile distilled water until homogeneous for 1 minute. Next, the mixture was put into plate $320 \mu \mathrm{l}$ and followed by incubating for 1 hour at $37^{\circ} \mathrm{C}$. The next step, the mixture was put into $640 \mu \mathrm{l}$ media RPMI-1640 and incubated at $37^{\circ} \mathrm{C}$ for 24 hours. The solution was filtered with $0.2 \mu \mathrm{m}$ (ministart).

Citotoxicity test of calcium hydroxide was done with cell culture (BHK-21) in cell line planted in roux bottle. After confluent, culture was harvested using trypsine versen solution. The harvest was taken little by little replanted in Rose Well Park Memorial Institute (RPMI-1640) media. Which contained $10 \%$ albumine serum of vital bovine incubated for 24 hours at $37^{\circ} \mathrm{C}$. Then cell with moved into roux bottle and was made with $2 \times 10^{5} \mathrm{cell} / \mathrm{ml}$ density. The cell was ready for sample testing.

Citotoxicity test using at the bottom of wells of 96 well cell culture plate. Citotoxicity test was done according to standard procedure for MTT assay. ${ }^{16}$ Every well contained cell + RPMI $100 \mu$ l with $2 \times 10^{5}$ cell $/ \mathrm{ml}$ density in the amount of $50 \mu \mathrm{l}$. Prior to the test, calcium hydroxide solution sample was sterilized using ultra violet for 15 minutes, next, $50 \mu 1$ sample was put into well cell culture plate. On this study, the test was done twice (duplo). Then, well cell culture plate was incubated for 20 hours at $37^{\circ} \mathrm{C}$. Followed by every well was filled $25 \mu 1$ of $5 \mathrm{mg} / \mathrm{ml}$ MTT which had been solved in PBS, incubated for 24 hours at $37^{\circ} \mathrm{C}$. then every well was added by $50 \mu 1 \mathrm{DMSO}$. Finally, well cell culture plate was read on spectrophotometer with $595 \mathrm{~nm}$ wave length.

The result was stated in optical density (absorbent). The amount of absorption in every well showed the number of survive cell in media culture. ${ }^{17}$ On this study, the data of survive cell measurement of citotoxicity test. Using enzymatic test with method of MTT (3-(4.5-diethyl thiazol-2yl), 2.5 diphenyl tetrazolium bromide. The study sample was divided into 5 groups of calcium hydroxide in different concentration i.e. group I (50\%), II (55\%), III $(60 \%)$, IV (65\%) and V (70\%) in which every group consisted of 8 samples. The data was taken from statistical One-Way ANOVA test with significance limit $\alpha=5 \%$, then followed by LSD.

\section{RESULT}

The result of the study on citotoxicity of calcium hydroxide done on fibroblast cell (BHK-21) using 40 samples classified into 5 groups. Each group consisted of 8 sample with different concentration of calcium hydroxide group I: $50 \%$, group II: $55 \%$, group III: $60 \%$, group IV: $65 \%$ and group V: $70 \%$.

The mean and deviation standard of various concentration calcium hydroxide on fibroblast cell BHK-21 could be seen on table1.

Citotoxicity test shows the calcium hydroxide in various concentration $(50 \%, 55 \%, 60 \%, 65 \%$ and $70 \%)$ on fibroblast cell BHK-21. The result shows that calcium hydroxide in concentration $60 \%$ (group III) has reached the highest number of survive cells comparing with other concentration. It is showed on Figure 1. 
Table 1. The mean deviation standard of citotoxicity test in various concentration calcium hydroxide on fibroblast cell BHK-21 in optical density (OD)

\begin{tabular}{lccc}
\hline \multicolumn{1}{c}{ Concentration } & $\mathrm{N}$ & $\overline{\mathrm{X}}$ & $\mathrm{SD}$ \\
\hline Group I & 8 & 0,70500 & 0,075848 \\
Group II & 8 & 0,75638 & 0,092657 \\
Group III & 8 & 0,77350 & 0,091147 \\
Group IV & 8 & 0,76400 & 0,070751 \\
Group V & 8 & 0,74075 & 0,076282 \\
\hline
\end{tabular}

Note : $\mathrm{N}=$ The number of samples

$\overline{\mathrm{X}}=$ Mean of the number survive cell

$\mathrm{SD}=$ Standard deviation

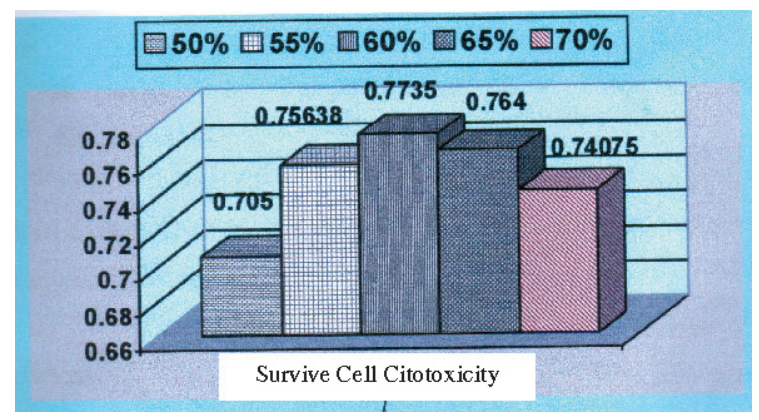

Figure 1. Graphic of mean of survive cell citotoxicity test calcium hydroxide various concentration toward fibroblast.

Table1 shows that citotoxicity test of calcium hydroxide done on fibroblast cell (BHK-21) in 5 groups, each group consists of 8 samples. Group III $(60 \%)$ shows the mean of the highest number survive cells: 0.77350 , while group I $(50 \%)$ shows the mean of the lowest number survive cells: 0.70500 . The data on table 1 was achieved from homogenecity test with Lavene Statistic, $p=0.557$ ( $p>0.05$ ), meaning the data is homogeneous and normal distribution using one sample Kolmogorov Smirnov Test. The citotoxicity effect was analyzed by One-Way ANOVA statistically $\alpha=5 \%$ (Table 2 ).

Table 2. The result of One-Way ANOVA direction citotoxicity test in various concentration calcium hydroxide toward fibroblast cell BHK-21

\begin{tabular}{lccccc}
\hline & TS & FL & MS & C & Sig \\
\hline $\begin{array}{l}\text { Inter } \\
\text { group } \\
\text { on } \\
\text { group }\end{array}$ & 0,023 & 4 & 0,005756 & 0,988 & 0,427 \\
\hline \multicolumn{1}{c}{ Total } & 0,204 & 35 & 0,005826 & & \\
\hline Note: & TS : & total square; & FL : & free level; \\
& MS : & mean square; & C : & calculation; & \\
& Sig : & significant & & & \\
& & & & &
\end{tabular}

The result of One-Way ANOVA test showed no significant difference among control groups $\mathrm{p}>0.05$.

\section{DISCUSSION}

Clinical used of pure calcium hydroxide as intracanal dressing on endodontic treatment is generally in the form of paste. Mixing calcium hydroxide powder and sterile distilled water as vehicle could make calcium hydroxide paste. Calcium hydroxide $50 \%$ is generally used at the clinic. Besides sterile distilled water as vehicle, calcium hydroxide could be combined with other solution such as: glicerin, methyl celllose, buffer saline, local anesthetic solution etc. ${ }^{3,4}$

A material that is used as intracanal dressing in endodontic treatment should be antitoxic. Chang Chao ${ }^{18}$ supports this idea suggested that biological and toxicological aspects of a material clinically used are very important. To use calcium hydroxide as intracanal dressing in endodontic treatment is always expected to have low toxicity. Pissiotis and Spangberg ${ }^{7}$ stated that excessive calcium hydroxide pasta in root canal filling would not cause irritation and no symptom of inflammation was found in apical region. The above idea was against the opinion of Vajrabhaya et al. ${ }^{8}$ stated either intracanal dressing or sealer which flowed out of root canal would not induce periapical tissue irritation, while according to Schawrtz ${ }^{10}$ stated it is dangerous, if calcium hydroxide flows out of alveolaris inferior canal it would cause neurotoxic. The opinion is also supported by Wayman et al. ${ }^{19}$ that 17 of 58 cases found to require periapical surgical treatment due to endodontic failure caused by sealer flowing to periapical.

The use of calcium hydroxide as intracanal dressing in various concentrations, up to now the safety factor toward periapical and adjecent tissue in oral cavity is still unknown. One of the requirements for dentistry material which is applied in oral cavity should be biocompatible i.e. no substance with toxic content. To prove that the material is safe and nontoxic, invitro cytotoxicy test should be done on fibroblast cell culture taken from Baby Hamster Kidney (BHK-21) using enzymatic test i.e. MTT method in which fibroblast cell is dominant cell in pulp component, periodontal ligament and gingival. This cell line has been widely used to perform toxicity test on material and medicine in dentistry field. The advantages of using cell line culture are passage 50-70 times could be done, having high cell growth, cell integrity is well preserved and cell is capable to multiply in suspension. Enzymatic test with MTT method [3-(4.5 dimethyl thiazol-2yl)-2.5 diphenyl tetrazolium bromide] is a method that is widely used to test citotoxicity of material or medicine in dentistry field and to measure quantitatively cellular proliferation or living cell. The use of this method is based on various reasons such as: accurate and sensitive result could be achieved by using spectrophotometer which could clearly detect cell metabolism change, could be easily manipulated, the 
device could be easily acquired and available at laboratory, efficient and without isotop radioactive. ${ }^{11,17}$

MTT method determines the capability of living cell to reduce MTT. The mechanism is tetrazolium (yellow color) would be reduced in cell, which has metabolic activity. Mitochondria of living cell would express dehydrogenase enzyme, which has an important role in this process. If mitichondria were not active due to toxicity of a substance, cell metabolism would be disturbed. So dehydrogenase enzyme could not be excreted consequently formazan, which has been formed, would be equal to the enzymatic activity of living cell. ${ }^{11,17,20}$ Table 1 shows: cytotoxic strength of calcium hydroxide as intracanal dressing in fibroblast cell (BHK-21), there is no significant difference in concentration $50 \%, 55 \%, 60 \%, 65 \%$, and $70 \%$ calcium hydroxide paste. It means that there is no difference in toxicity in all groups of calcium hydroxide test in various concentrations.

Calcium hydroxide paste $60 \%$ shows optical density of detected survive cell is 0.77350 higher comparing with calcium hydroxide in other concentration. In this concentration the number of survive cells is the highest since calcium hydroxide $60 \%$ is still capable to stimulate the cells so calcium hydroxide would release high calcium ion resulting the increase of alkaline phosphatase (ALPase) enzyme activity consequently proliferation of fibroblast cell (BHK-21) would increase.

The result of study also shows that in calcium hydroxide $65 \%$ and $70 \%$ the numbers of survive cells decrease. Because calcium hydroxide has already reached saturated point toward viscosity so it is difficult to release calcium ion consequently it would decrease the activity of alkaline phosphatase (ALPase).

Some in vitro studies on calcium hydroxide, one of studies done by Rashid et $a .^{21}$ has proved that by adding $\mathrm{CaCl}_{2} 4 \mathrm{mM}$ in human pulp cell which has been measured, resulting the increase of alkaline phosphatase (ALPase) activity so pulp cell proliferation would occur, however by adding $0.7 \mathrm{mM}$ decreasing alkaline phosphatase (ALPase) activity in pulp cell would cause decreasing the number of pulp cell. Collagen synthetisis and alkaline phosphatase would increase simultaneously with the increase of $\mathrm{pH}$ medium until 8. Calcium hydroxide in water would decompose into calcium ion and hydrixil ion. Calcium ion, which is the content of calcium hydroxide, has an important role in cell calcification.

Chang Chao ${ }^{18}$ suggested calcium hydroxide could produce calcified barrier at the end of apical root done in vivo study, while Hasoya ${ }^{22}$ stated that calcium ion could improve circulation in capillary vessel, which could resist the effect.

It is concluded that in concentration $60 \%$ calcium hydroxide shows the lowest toxicity comparing with calcium in concentration $50 \%, 55 \%, 65 \%$, and $70 \%$. While among the control groups there is no significant difference. Sugesstion: It is necessary to perform further study on animal experiment to know the strength of citotoxicity of calcium hydroxide pasta in concentration $60 \%$.

\section{REFERENCES}

1. Grossman LI, Oliet S, Del Rio CE. Ilmu Endodontik dalam praktek. Ebyono R, editor. Cetakan I. Jakarta: Penerbit Buku Kedokteran EGC; 1995. p. 248-50, 256.

2. Widodo T. Paradigma baru pada perawatan endodontik. Kumpulan naskah seminar sehari tema ramah tamah perlakuan pada jaringan gigi. IKORGI; 2000; p. 2, 6-7.

3. Siqueira JF, Uzeda M. Influence of different vehicle on the antibacterial effect of calcium hydroxide. J Endod 1998; 24(10):663.

4. Solak $\mathrm{H}$, Oztan MD. The $\mathrm{pH}$ change of four different calcium hydroxide mixture used for intracanal medication. J Oral Rehab 2003; 30:436-9.

5. Estrela C. Calcium hydroxide: study based on scientific evidence. J Appt Oral Sci 2003; 11(4):269-82.

6. Cohen S, Burn RC. Pathways of the pulp. $6^{\text {th }}$ ed. St Louis: Mosby; 1994. p. 211-12, 486-507.

7. Pissiotis, Spangberg ISW. Biological evaluation of collagen gels containing calcium hydroxide and hydroxiapatite. J Endod 1990; 16: 369 .

8. Vajrabhaya L, Sithisam P, Wilairat P, Leelaphiwat S. Comparison between Sulphorhodamine-B dye staining and 51 release method in cytotoxicity assay of endodontic sealers. J Endod 1997; 23(6):355-57.

9. Stock CJR, Nehammer CF. Endodontic in practice: The modern concept of endodontic. $2^{\text {nd }}$ ed. London: British Dental Association; 1990. p. 1-10, 23-27.

10. Schawrtz RG, Dreyer M, Aydin M. The opinion within this web peg are not our. Authors have been credited for the individual post where they are. Available at: www.rxroot.com-X-Rays. Courtesty. Dental India Home page. Accessed May 23, 2005.

11. Meizarini A. Sitotoksisitas bahan restorasi cyanoacrylate pada variasi perbandingan powder dan liquid menggunakan MTT assay. Majalah Kedokteran Gigi (Dental Journal) 2005; 38(1):20-24.

12. Van Noort R. Introduction to dental material. $2^{\text {nd }}$ ed. London: CV Mosby Company; 2003. p. 3-5.

13. Fazwishui S, Hadijono BS. Uji sitotoksisitas dengan esei MTT. JKGUI 2000; 7:28-32.

14. Freshney RI, Culture of animal cells. A manual of basic technique. $2^{\text {nd }}$ ed. New York: Alan R Liss Inc; 1987. p. 9, 71, 128, 239.

15. Estrela C, Pimenta FC, Ito Yoko I, Bammann L. In vitro determination of direct antimicrobial effect of calcium hydroxide. J Endod 1998; 24(1):15-17

16. Dash P. Standard protocols MTT assay (kutipan dari Yuliati A. Majalah Kedokteran Gigi (Dental Journal) 2004). Available from: http://web.bham.ac.uk/can4psd4/brum/mtt.html. Accessed January 8, 2002.

17. Yuliati A. Viabilitas sel fibroblast BHK-21 pada permukaan resin akrilik rapid heat cured. Majalah Kedokteran Gigi (Dental Journal) 2005; 38(2):68-71.

18. Chang Chao Y, Huang Fue M, Cheng HM. In vitro evaluation of the cytotoxicity and genotoxicity of root canal medicine on human pulp fibroblast. J Endod 1998; 24(9):604-06.

19. Wayman BE, Murata SM, Almeida RJ, Fowler CB. A bacteriological and histological evaluation of 50 periapical lesion. J Endod 1992; 18:152-5.

20. Telli C, Serper A, Dogan L, Gug D. Evaluation of the cytotoxicity of calcium phosphate root canal sealer by MTT assay. J Endod 25 1999; 25(12):811-13.

21. Rashid F, Shiba H, Mizuno N. The effect of extracellular calcium ion on gene expression of bone related protein in human pulp cells. J Endod 2003; 29(2):104-5.

22. Hosoya N, Takashi G, Arai T, Nakamura J. Calcium concentration and $\mathrm{pH}$ of periapical environment after applying calcium hydroxide into root canal in vitro. J Endod 2001; 27(5):343-46. 